\title{
CHALLENGES IN TEACHING AND LEARNING FOREIGN LANGUAGES OTHER THAN ENGLISH: COMPARATIVE ANALYSIS OF ENGLISH AND SPANISH PHONETICS
}

\author{
Victoria Davtyan \\ Senior lecturer, Peoples` Friendship University of Russia (RUDN University), \\ RUSSIAN FEDERATION, davtyan_vv@pfur.ru
}

\begin{abstract}
Nowadays learning foreign languages has become a necessity that involves extensive study of major European languages: Spanish, French or German. In recent years, Spanish is known to be widely used as a second foreign language by the majority of Russian students.

The paper explores the experience of the RUDN University Law Institute with regard to foreign language learning/teaching.

Most of first year students at Law Institute of RUDN University (Peoples' Friendship University of Russia), follow the curriculum requirements that envisage the learning of two foreign language, for example, English as a first language and Spanish as a second one.

The paper names the main reasons why the students choose Spanish as a second foreign language. It is believed that the students who have already some experience in learning a first foreign language, the learning of a second foreign language should go more smoothly.

However, in fact they face a lot of problems that make both positive and negative effect on their learning the second foreign language.

In this paper the author conducts a comparative analysis of English and Spanish phonetics. The paper also demonstrates an analysis of the experience in teaching these languages to the non-language students and the difficulties that can emerge during the learning process.

The research findings contribute to further development of two foreign language university-based teaching to non-language students, highlight the issues of interference, maps potential errors, consider examples of tasks and assignments.

The findings can be used in the classroom of Spanish as a second foreign language, in the CPD and university degree courses for teachers of Spanish as a foreign language.
\end{abstract}

Keywords: Second foreign language learning, Spanish, university curricula for non-language students. 


\section{INTRODUCTION}

Globalization, mutual integration and the growth of international contacts between countries make it necessary to master foreign languages not only for professional linguists, but also for professionals of all specialties and training profiles.

At the same time knowledge of not one, but two or more foreign languages is often required, since proficiency in English, which is mainly studied as the first foreign language, is not so surprising to anyone.

Furthermore, modern universities strive to implement curricula with two foreign languages for non-language students as it contributes to internationalization and academic excellence (Atabekova et al., 2016).

However, it is mistakenly believed that only English is an international language. International languages are those that serve not only as a means of communication of the respective nation, but are also the official languages in several countries.

All over the world they are taught as a foreign language and used as a constant means of communication between representatives of two different peoples, especially if they do not speak each other's languages. Spanish, along with such languages as German, French, Chinese, is also considered an international one.

Scholars from different countries provide similar arguments for the fact why students choose Spanish as a second foreign language (Lasagabaster, 2017; Fontecha, 2020).

In Russia this choice is dictated by the similar reasons, as well:

- Spanish is a working language of the UN and other international organizations that increases its global importance;

- It is becoming more and more popular every year;

- It is one of the leading languages after English and Chinese;

- It is spoken in 21 countries;

- about 45 million people speak Spanish in the USA;

- knowing Spanish and English one can communicate with the great part of Europe and America;

- It is an easy language;

Taking into account the last argument the students are deeply mistaken that we can see further.

\section{METHODOLOGICAL BACKGROUND}

The methodological background for empirical class room practices implementation and their observation rests on a number of didactic provisions, namely the following:

A conceptual framework for the integration of language and content in second/foreign language instruction (Snow et al., 1989)

The issue of motivation in second and foreign language learning (Dörnyei, 1998, Khong et al., 2017, lu et al., 2019)

The analysis of challenges students face when learning Spanish (Anaya Castañeda, 2018; Moreno-López et al., 2017)

The analysis of errors forms the angle of interference in the course of second/foreign language learning and their interpretations (Wood, 2017).

The changing landscape of Spanish language curricula for diverse students (Brown, Thompson 2018)

The importance of pronunciation training (Huensch, 2019).

The above data were taken into consideration for the practical training of Spanish phonetics with students who had learnt English as a foreign language before.

\section{FINDINGS AND DISCUSSION}

Learning any foreign language starts with the introduction of the rules of reading. Touching this aspect, it should be noted that in German, French and Spanish there are strict rules of reading. 
As the Spanish language has clear rules of reading, a student is expected to be able to read any word without its help.

Theoretically is widely believed the students already have experience of studying the first foreign language, so mastery of a second foreign language articulation and pronunciation should go more smoothly. But practice shows quite the opposite: knowledge of English reading rules negatively affects the teaching process of Spanish phonetics.

From the very beginning the students face a lot of problems and make the typical mistakes in the pronunciation of the sounds (articulation): the vowels a/o cannot be reduced e.g. color/calor, contar/ cantar, mano/mono. They should be pronounced like [kolor/kalor], [kontar/kantar], [mano/mono]. The diphthongs "ue/ ua" cannot be weak e.g. guapo, cuaderno, suerte, puerta, where both vowels should be pronounced.

Another key difference is that unlike the Spanish language English reading rules are extremely vague and unstructured which suggests the presence of transcription.

The word "hotel" in English is pronounced with the consonant sound [h] but in Spanish it should be omitted and the word is pronounced like [otel] (Uso de la letra $\mathrm{H}, \mathrm{n} / \mathrm{d}$ ).

This rule can be also observed in the words "hermano", "hogar", "cohecho", etc. Other examples are: consonants "s/z" cannot be vocalized in the words "visita, taza, esfuerzas"; letters "que-qui" cannot be read as [kwe-kwi] but as [ke-ki], for instance, the words " quebrar/ quitar/queso/quiso".

There has been presented a short list of mistakes made by the students that can be continued. Researchers distinguish the following reasons for the students' mistakes: interlingua interference, into lingual interference, a psychological language barrier, the fear of making mistakes (Turchenko, Chmyreva 2014).

To avoid these mistakes it is necessary to incorporate more assignments aimed at distinguishing different sounds in two foreign languages (Vowels and Consonants in Spanich. Pronunciation, n.d). .

One of the most popular assignments are rhymes, tongue twisters, proverbs or sayings (Idioms with say tell - speak - talk, n/d).

As our students are supposed to have some proficiency level at another foreign language (English) it is possible to use the examples from two foreign languages. This approach can help to show the difference or similarity in English and Spanish pronunciation.

If the students are given the following tongue twisters for drilling the pronunciation of the sound [l] in English e.g "Luke's duck likes lakes. Luke Luck licks lakes." and in Spanish e.g "¡Hola, Adela! Dile a Dalila que dé la lila a la Lola" they can see that the sound [ I] is resonant and remains hard in front of the vowels in both languages, but in Spanish it is more alveolar (gingival) (My Spanish, n/d; Tongue Twisters, $\mathrm{n} / \mathrm{d}$ ).

It is necessary to point out one rule that is present in both languages: the consonants "c" and " $\mathrm{g}$ " " are pronounced as [s] and [d]] in front of the vowels "e, i, y". In Spanish the words "cine, cerca/ agenda, Gibraltar are read with almost the same sounds[s] and [h] but not [k] and [g].

If this rule is not learned by the students well, if the students cannot pronounce these consonants correctly and often make mistakes in English, they keep on making the same mistakes in Spanish.

On the contrary, if students are aware of the rule and have a strong skill of the correct pronunciation they transfer the skill of the first foreign language and do not make such a mistake in the second foreign language.

There have been named a number of typical phonetical mistakes made by the students in the learning process. The author is sure that such kind of mistakes must be corrected at the very initial stage of learning a foreign language. It should be done during all learning process in order not to prevent comprehension in speech activity.

Further it should be mentioned that digital simulators that have been cited earlier in this paper can contribute to the students' pronunciation self-training, and in current circumstances it can be launched through the digital cloud that is traditionally considered as a tool to overcome the knowledge (Atabekova, 2015, Chan et al., 2018).

The above data should be viewed as part of the overall university-based several foreign languages learning/teaching process that is supposed to enhance Multilingualism in Higher Education through the first steps of foreign language learning (Atabekova, 2016, Hirosh, Degani, 2018). 


\section{CONCLUSIONS}

The empirical data provided in the paper reveals those sensitive points which do matter in the course of teaching Spanish as a second foreign language to students whose first foreign language is English.

The material focuses on the phonetics and pronunciation issues as they are the starting point for the adequate perception of oral communication in a foreign language and for the relevant production of oral speech in a foreign language, as well.

Further, the empirical material is considered from the angle of interference. Its consideration might contribute to errors forecast and their timely correction.

Moreover, error-based analysis of comparative nature with regard to pronunciation training can help students analyze their learning steps and tactics.

The findings can be used in the classroom of Spanish as a second foreign language, in the CPD and university degree courses for teachers of Spanish as a foreign language. Further studies might be relevant with regard to different national variants of Spanish and their specifics in the subsystem of pronunciation and phonetics.

\section{REFERENCE LIST}

Anaya Castañeda, S. (2018). Linguistic challanges faced by native american students learning spanish at a spanish teaching institution (Bachelor's thesis, Benemérita Universidad Autónoma de Puebla).

Atabekova, A. (2015). Foreign Language and Mediation Skills training in the Cloud to Overcome Knowledge Divide. 9th International Technology, Education and Development Conférence (INTED). Madrid, Spain, March 02-04, 6482-6485.

Atabekova, A. (2016). Multilingualism in Higher Education: pros and Cons according to University Students. 10th International Technology, Education and Development Conference (INTED). Valencia, SPAIN, March 07-09, 4947-4954

Atabekova, A., Belousov, A. Shoustikova, T. (2016). Vernacular and Foreign Languages in Higher Education as Driving Tools for International University Academic Excellence. ADVED 2nd International Conference on Advances in Education and Social Sciences. Istanbul, Turkey, October 10-12, 554-558.

Brown, A. V., \& Thompson, G. L. (2018). The changing landscape of Spanish language curricula: Designing higher education programs for diverse students. Georgetown University Press.

Chan, M. M., Plata, R. B., Medina, J. A., Alario-Hoyos, C., \& Rizzardini, R. H. (2018). Modeling educational usage of cloud-based tools in virtual learning environments. IEEE Access, 7, 13347-13354.

Dörnyei, Z. (1998). Motivation in second and foreign language learning. Language teaching, 31(3), 117-135.

Fontecha, J. C. A. (2020). An Action Research Study on the Use of Flipped Learning in a Spanish as a Foreign Language Class (Doctoral dissertation, Illinois State University).

Hirosh, Z., \& Degani, T. (2018). Direct and indirect effects of multilingualism on novel language learning: An integrative review. Psychonomic Bulletin \& Review, 25(3), 892-916.

Huensch, A. (2019). Pronunciation in foreign language classrooms: Instructors' training, classroom practices, and beliefs. Language Teaching Research, 23(6), 745-764.

Idioms with say - tell - speak - talk( n/d). Anglofeel. https://anglofeel.ru/lessons/idiomy-s-say---tell---speak--talk

Khong, H. K., Hassan, N. H., \& Ramli, N. (2017). Motivation and gender differences in learning Spanish as a foreign language in a Malaysian technical university. Malaysian Journal of Learning and Instruction, 14(2), 59-83.

Lasagabaster, D. (2017). Language learning motivation and language attitudes in multilingual Spain from an international perspective. The Modern Language Journal, 101(3), 583-596. 
Lu, X., Zheng, Y., \& Ren, W. (2019). Motivation for learning Spanish as a foreign language: the case of Chinese L1 speakers at university level. CÍRCULO de Linguística Aplicada a la Comunicación, 79, 79.

Moreno-López, I., Ramos-Sellman, A., Miranda-Aldaco, C., \& Gomis Quinto, M. T. (2017). Transforming ways of enhancing foreign language acquisition in the Spanish classroom: Experiential learning approaches. Foreign Language Annals, 50(2), 398-409.

My Spanish (n/d). http://myspanish.ru/?p=492

Snow, M. A., Met, M., \& Genesee, F. (1989). A conceptual framework for the integration of language and content in second/foreign language instruction. TESOL quarterly, 23(2), 201-217.

Tongue Twisters (n/d). http://www.english-easy.info/tonguetwisters/sonorant.php\#axzz6hvc1mKxn

Turchenko N.P, Chmyreva Ye.V. (2014) Typology of mistakes in the course of teaching the second foreign languageand their correction (In Russian). Science Time, 10 (10).

[https://cyberleninka.ru/article/n/tipologiya-oshibok-v-protsesse-obucheniya-vtoromu-inostrannomuyazyku-ispanskiy-yazyk-i-ih-korrektsiya]

Uso de la letra H (n/d). Deperu. https://deperu.com/abc/gramatica/752/uso-de-la-letra-h

Vowels and Consonants in Spanich. Pronunciation (n.d). https://childer.ru/vowels-and-consonants-inspanish-spanish-alphabet.html https://childer.ru/vowels-and-consonants-in-spanish-spanishalphabet.html

Wood, J. F. (2017). Errors in second/foreign language learning and their interpretations. Education and Linguistics Research, 3(1), 1. 